\title{
Dinamika és komplexitás romák etnikai és nyelvi (ön)definícióiban
}

\author{
2. rész
}

3. Dualisztikus és dinamikus modellek. Három év alatt egy nyelvészeti etnográfiai kutatás résztvevőjeként mintegy száz napot töltöttem egyetemi kutatócsoportot vezetve egy olyan kelet-magyarországi város egyik településrészén, amelyet helyben Majorosnak hívnak, és amelynek lakói nem kis részben úgymond kétnyelvüek, és úgymond romaniul is beszélnek. A majorosi városrész magja egy telepként emlegetett lakóterület, amelyet néhány további utcával együtt egy vasút- és föútvonal választ el a város többi részétől. A majorosi városrész lakóinak többsége magát romának vagy cigánynak mondja, a városban pedig cigányként tartják őket számon. Munkánk során etnográfiai interjúkat készítettünk körülbelül 60 felnőtt emberrel (24 órányi hangfelvétel). Az iskolában és az óvodában, ahová ebből a városrészből járnak a gyerekek, meglátogattunk 90 iskolai tanórát, csoportfoglalkozást, amelyeken felvételeket vagy jegyzeteket készítettünk. E munka következményeképpen együttmüködésbe fogtunk a helyi pedagógusokkal (vö. Transzlingvális osztálytermi kommunikáció és hatékony tanulásszervezés c. projekt - www.translangedu.hu). Munkánk a helyi romani beszédmódok iskolai bevezetését célozza, amitől a gyerekek nagyobb iskolai sikereit reméljük.

A terepmunka egyik legfontosabb tanulsága, hogy a helyi roma közösség tagjainak etnicitásról és nyelvről szóló gondolkodását csak részben határozza meg a csoportszemlélet. Az interjúk, illetve a beszélgetések során újra és újra feltettük ugyanazokat a kérdéseket: Hogyan beszélnek itt? Hogyan tanulnak meg beszélni? Hogyan tudnak könnyen, bátran beszélni? Hogyan szeretnek beszélni? - és így tovább. Beszélgetőtársaink mindig válaszoltak kérdéseinkre, de sok eltérő választ kaptunk, és ezek nem is mindig korreláltak egymással.

A közösségben arra a kérdésre, hogy milyen romák ők, általában annyit mondanak, hogy romák, esetleg azt, hogy oláhcigányok. A három év alatt nem hangzott el ehhez képest más, ellenben a nyelvi heterogenitás újabb és újabb dimenziói tárultak fel a beszélgetések során. A megkérdezettek úgy vélekednek, hogy másképp beszélnek például a közösség lakóhelyének egyik szegletében, mint a másikban. Vagy máshogy beszélnek a különböző családneveket viselök. Eltérö módon beszélnek továbbá a fiatalok és az idősebbek, a szegényebbek és a módosabbak. Máshogy beszélnek azok, akik a városban születtek, és akik nem; azok, akiknek a városból való házastársuk van, és akiknek nem. Jellemző vélekedés az is, hogy a helyi romák máshogy beszélnek, mint más városokból származó romák. Es mindenki máshogy fogalmazza meg a különbségeket, máshogy mondja el, hogy

*Az első részt 1. MNy. 2020: 49-54.

Magyar Nyelv 116. 2020: 166-179. DOI: 10.18349/MagyarNyelv.2020.2.166 
ő hogy beszél, és hogy mások hogyan beszélnek. A sok máshogy nem csak arra vonatkozik, hogy ki beszél többet cigányul, és ki többet magyarul. Ugyanis ebben a közösségben máshogy gondolják el e kettő különbségét és egymáshoz való viszonyát is. Nem úgy szólnak ezekről, ahogy mi kérdeztünk. A „,vagy-vagy”, „és-és” vagy az „is-is” dualitásai helyett megszólalásaikban inkább a beszélés pillanatait, feszültségeit, dinamikáját és végső egységet feltételező sokféleségét írják körbe. Mindezeket a továbbiakban néhány beszélgetésrészlettel illusztrálom.

A beszélők változatos módokon írják le, hogy melyik nyelvhez köthető elsődlegesen a családi kommunikáció. Egyes családokban romani dominanciáról számolnak be, más esetekben magyar dominanciát emlegetnek, de szinte minden esetben sietnek a kiegészítéssel, hogy ez nem jelent kizárólagosságot. A 46 éves Móni erről az alábbi módon számol be. (A beszélgetésrészletekben szereplő helyiek keresztneveit megváltoztattam. A négyszemközti beszélgetést vezette Flumbort Ábel hallgató 2018 februárjában. Ez és a többi 2018. februári felvétel az iskolában készültt. ${ }^{1}$

Ábel És otthon hogyan szoktak beszélni?

Móni Csak cigányul. [nevet, Ábel közbeszól: Csak cigányul?] Igen. Csak cigányul. A kis unokáimmal is cigányul beszélünk, a párommal is, a gyerekekkel is, cigányul.

Ábel És akkor a magyart azt így otthoni környezetben nem?

Móni Nem. Nem. Nem nagyon használjuk. Mán úgy a lányaim, Ági, Abigél, mán a kisgyerekekkel [értsd: Móni unokáival] beszélnek magyarul is, hogy azt is értsék meg [ti. ha óvodába mennek], de én nem, csak cigányul. De a lányok mán igen.

Hasonlóan romani dominanciáról számol be a 38 éves Irén is (a négyszemközti beszélgetést vezette Flumbort Ábel, 2018 februárjában):

Ábel És akkor otthon mennyire szokták a magyart használni?

Irén Nem is szoktuk. [Ábel közbeszól: Egyáltalán nem?] Nem.

Ábel Soha?

Irén Háát (.) hogy mondjam? Ritkán. Mikor úgy beszélek, akkor (.) ritka. (...) Ábel És ez mitöl függ? Mikor van ilyen kedve?

Irén Mit tudom én, mikor például bejön a kis unokám, azt magyarul szól hozzám. (.) Mert valamikor hazajön az oviból, és szól magyarul, én meg viszszaszólok neki magyarul. (.) Ügyes vagy, akkor már jól megtanultad azt a (.) magyar nyelvet.

A következő, 2019 januárjában készült beszélgetésben Alex (kb. 30 éves), aki óvodás és kisiskolás korú gyermekek édesapja, másféle, dominánsan a magyarhoz kapcsolt nyelvi szocializációs mintákról számol be, de ő is felhívja a figyelmet, hogy a gyerek mindennapjaiban jelen van az elsődlegesen romanihoz köthető kommuni-

${ }^{1}$ Jelmagyarázat: [ ]=lejegyző megjegyzése; - = félbeszakadt megnyilatkozás; (.) = szünet; $(\ldots)=$ lejegyzésből kihagyott részlet; $\mathrm{x}=$ érthetetlen szótag). 
káció is. (A beszélgetést készítették Czumpft Krisztina és Eva Hoyt-Nikolić hallgatók 2019 januárjában az óvodában, a felvétel készítésekor jelen volt egy óvónő is.)

Alex [Kislányom (keresztnév)] az szinte úgy nött föl, hogy alig beszéltünk hozzá cigányul. Nagyanyámék beszéltek. Vagyis anyukámék, nagyanyámék, azok beszéltek vele cigány nyelven. Azért tud cigányul.

A beszélők nemcsak kerülik a kizárólagosságot, hanem gyakran el is mozdítják a beszélgetés során az arról megfogalmazott álláspontjukat, hogy melyik nyelvhez köthetők inkább a család nyelvi (szocializációs) gyakorlatai. Alex előbb azt hangsúlyozza, hogy felesége családja, bár a telepen él, ,, otthon is, egymás között az a család, az magyarul beszélget”. Ennek az a következménye, hogy felesége ,igy nevelkedett, tehát valahogy magyarul beszélt, és velem is, én is úgy tudok vele csak beszélgetni, magyarul". Ezután azonban azt is mondja, hogy vele együtt felesége is ért és beszél cigányul, és ennek a gyerekekkel való kommunikációban is megvan a szerepe. (A beszélgetés során már nem kerül szóba, hogy van-e különbség az egy-két évvel idősebb fiúk és az óvodáskorú kisebb lány nyelvi szocializációja között, immár általánosságban van szó a három gyermekkel való kommunikációról):

Kriszta Ühüm, de hogy mind a ketten egyébként értik is és beszélik is a cigány nyelvet, tehát ön is és a felesége is.

Alex Persze, persze.

Kriszta És akkor a gyerekekkel való kommunikációban hogyhogy mégis a magyar, és hogyhogy nem a cigány nyelv, azt hogyhogy nem hozták bele, hogy a gyerekekkel cigány nyelven is beszéljenek, hogyha a nagyszülök is-

Alex Nem azt mondom, hogy nem beszélünk velük cigányul

Kiszta Tehát hogy akkor mind a két nyelven

Alex Mind a két nyelven. Persze.

Egy, az általános iskolás korú unokáit maga nevelő nagymama, Magda a vele készült beszélgetésben (készítette az iskolában Flumbort Ábel 2018 februárjában) megjegyzi, hogy az olyan családok gyermekei, ahol egy szülő vagy nagyszülő nem cigányként van számon tartva a közösségben, esetenként letagadják romani nyelvi kompetenciáikat. Ugyanakkor Magda szerint ezek a gyerekek is kétnyelvü otthoni környezetben élnek. Az előző példához hasonlóan itt is azt láthatjuk, hogy a beszélgetés közben eltolódik Magda álláspontja, és a záró mondatban már nem csak a nagyszülőket, hanem a szülőket is említi a romanihoz köthető nyelvi gyakorlatok kapcsán:

Magda De télleg vannak olyanok, akik igen. Letagadják, hogy-ök nem tudnak cigányul, meg ök nem cigányok, de (\#\#) azok.

Ábel És akkor ők mondjuk otthon így hogyan beszélhetnek? Akik így letagadják, hogy tudnak cigányul, de aztán mégis.

Magda Szerintem magyarul beszélnek otthol is. (...) 
Ábel Tehát akkor ök a cigányt nem is használják?

Magda Nem használják, de viszont a nagyszülök, azok igen. Azok igen. És értik. Meg tudják is. Mer a nagyszülök, azok cigányul beszélnek velük. Meg a szülök is szoktak velük cigányul beszélni. Igen, csak ha úgy valahova mennek, akkor ők is olyan kitartók [értsd: kifelé tartanak a közösségböl], hogy már ök nem beszélik a cigány nyelvet.

Alex és Magda számára ezek az álláspontváltozások, látszólagos ellentmondások összeférnek. Beszélgetőtársaink gondolkodásában ugyanis - bár az egyes kódokat cigányként és magyarként megnevezik, illetve azokat egy-egy nyelvként számon tartják - nem úgy jelenik meg a romani nyelven beszélés és magyar nyelven beszélés, mint a kérdezők fejében.

Ennek két oka van. Egyrészt a helyi, romanihoz köthető beszédmódokban sok az olyan erőforrás, amelyeket a csoportszemlélet (és a nyelvészet tudós kategóriái) magyar jövevényszóként írnak le. Magda erről azonban máshogy, a kettő valamiféle azonosságát feltételezve beszél: „,A- mi cigányul beszéltünk [értsd: beszélünk, nyelvbotlás], majdnem egyforma a magyarral. Tehát vetekszik. Valamit cigányul elmondunk, és azt megérti a magyar is, hogy én most mit mondtam. Igen. Hát mondjuk van egy (...) mondjuk ez pohár. Mi cigányul is annak mondjuk”. Móni sem magyar szavaknak tartja a jövevényszavakat, hanem romani szavaknak, amik olyanok, mint a magyar szavak: ,, Mert mink, van olyan kifejezésünk, hogy magyar. Mintha magyarul mondanánk el, csak másként. De magyarok is megértik". Ezek a mondatok a megszólalásokat nem magyarhoz és cigányhoz kötik, hanem egységet tételeznek.

Másrészt amikor a megkérdezettek a kérdezőkhöz hasonlóan elválasztják egymástól a két nyelvet, nem arra koncentrálnak, hogy hogyan váltanak a két nyelv között, hanem arra, hogy mikor melyik milyen arányban jelenik meg nyelvi gyakorlataikban. Az Alexszel készített beszélgetés egy késóbbi szakaszában a kérdezők a többi közösségbeli család jellemző nyelvi szocializációs stratégiáit firtatják. A közösséget munkájánál és majorosi lakhelyénél fogva is kiválóan ismerő óvónő (Zita) és Alex válaszai többet sorra vesznek azok közül a fejezet elején említett faktorok közül, amelyek mentén a beszédmódok helyi kategorizációja történik:

Kriszta És önnek igy mi a véleménye, hogy a telepi szülök a gyerekekkel inkább cigányul vagy inkább magyarul beszélnek? Többet? A gyerekekkel!?

Zita Erre nagyon nehéz válaszolni.

Alex Erre nehéz, nagyon.

Zita Tehát az a gond, hogy ehhez az egész telepnek a szerkezetét le kell képezni, mert (...)

Kriszta És mondjuk a [utcanév 1] út vagy a [utcanév 2] út mentén $\langle x x x\rangle$.

Zita Ezt még utcákhoz se lehet kötni, mert az-.

Alex Nem, nem.

Zita Családokhoz.

Alex Családon belül lehet eldönteni.

Zita És mely családok, akik inkább magyarul, és mely családok, akik inkább cigányul beszélnek? 
Alex Na most ezt megint egy nehéz (...) ez szinte ugyanaz a kérdés.

Zita Tehát ezt névhez sem lehet kötni, mert ugye [családnév 1] is van többféle

Alex Igen, [családnév 2] is van sokféle, [családnév 3] is van sokféle. Van [családnév 4] is, meg [családnév 5] is, meg mit tudom én, még milyenek vannak ott lent. [családnév 6]. (...)

Zita (...) Az a baj, hogy a telepre költöznek folyamatosan, most például [városnév, szomszédos város]-ról jöttek többen, például [családnév 7], és ők kimondottan magyar anyanyelvüek.

Kriszta És ők nem is értik egyáltalán?

Zita De, a szerzett rokoni kapcsolat, meg a házasság révén kezdik. (...) hát szerintem a telepen mindenki érti a cigányt, én azt gondolom.

Alex Száz százalékba mindenki érti.

Zita De beszélni nem mindenki tud úgy.

Bár az első, a hallgatók által felvetett szempontot, a beszédmódok utcákhoz kötését az óvónő és nyomában az apa elvetik, utóbbi később egy fél mondat erejéig (,,mit tudom én még milyenek vannak ott lent”) mégis utal arra, hogy egyes családok a lakókörnyezet egyes részeihez köthetők. A lent általában a telepként emlegetett lakókörnyezet (amely egyúttal a Majorosnak nevezett városrész magja is) fơúttól távolabbi, elzártabb részére vonatkozik, ahol a házak sürübben épültek, és ahol a majorosiak vélekedései szerint alacsonyabb presztízsü, szegényebb és romani nyelven többet beszélő családok laknak. A „lenthez”, ahogy az itt is történik, konkrét családokat is kötnek a megkérdezettek. A következő felmerülő szempont, hogy az egyes családnevek szerint lennének különbségek a nyelvi szocializációban. A negyed mintegy 3000 főnyi lakója néhány kivételtől eltekintve hét családnév egyikét viselik. Az óvónő a beszélgetés egy korábbi részében épp a családnévvel ad magyarázatot a feleség magyar nyelvi dominanciájára. E ponton ugyanakkor az óvónő és Alex vélekedései egybevágnak a tekintetben, hogy az egy-egy családnévhez köthető beszélök között is vannak eltérések a nyelvi szocializáció milyenségét illetően, és a nyelvi szocializáció sokfélesége csak a mikrocsaládok szintjén írható le. Végül felmerül az a szempont is, hogy a beköltözések és egyéb lakhelyváltoztatások hogyan befolyásolják a nyelvi gyakorlatokat.

A sokféleséget e megközelítések nem dualitások soraként látják. Beszédmódjaikra a megkérdezett érintettek úgy tekintenek, mint amelyek komplex és dinamikus, folyamatosan változó rendszerbe szerveződnek. Bár köthetők az egyes nyelvekhez, a hangsúly nem az ezek közötti váltásokon van. Ehelyett mindkettő egyszerre van jelen a kommunikációban, a mindennapokban, és a beszélők számára fontosabb arányuk meghatározása. A pedagógusok, óvodapedagógusok ellenben, akik e közösség gyermekeit az óvodában és iskolában nevelik és tanítják, és akikkel szintén sokat beszélgettünk, jellemzően máshogy gondolkodnak. Ök a városban kétféle embert látnak: nem romákat (ahogy romák és nem romák helyben mondják: magyarokat), illetve romákat (ahogy helyben legtöbbször mondják: cigányokat). Utóbbiak esetében megkülönböztetik az iskolába járó gyerekek családjait a város másik végében lakó, szintén cigányként emlegetett emberektől. A megkülönböztetés alapja leginkább az, hogy ez utóbbiak nem beszélnek cigányul. A cigányok 
a városban tehát szerintük vagy (csak) magyarul beszélnek, vagy magyarul és cigányul is, tehát vagy egynyelvűek, vagy kétnyelvűek. A témában tájékozottabbak azt is mondják, hogy előbbiek magyarcigányok, utóbbiak oláhcigányok. Az oláhcigány közösség tagjainak kétnyelvüségét illetően ugyanakkor - annak ellenére, hogy ugyanabban az iskolában ugyanazokat a gyerekeket tanítják - megoszlik a pedagógusok véleménye: egyesek szerint a gyerekek csak magyarul beszélnek, mások szerint minden gyerek tud cigányul is. (Míg a helyiek szemlélete átmenetek, folyamatosságok feltételezését is lehetővé teszi, a csoportszemlélet e tekintetben is vagy-vagy viszonyt érzékel: vagy tud/ért a gyerek cigányul, vagy nem.) A pedagógusok a gyerekek nyelvi gyakorlatainak leírásakor pedig a kódok közötti váltás kulcsmozzanatára támaszkodnak. Az elemzett interjú egy másik részletében az óvónő például így számol be a gyerekek óvodai nyelvi gyakorlatairól:

„,amikor szabad játék van, akkor (...) attól függ... attól függ, hogyha csatlakozik a játszócsoporthoz olyan gyermek például, aki mondjuk [családnév], vagy teljesen mindegy, de inkább ö magyar... inkább a kommunikációjában inkább a magyar nyelvet részesiti elönyben, akkor váltanak. Akkor magyarul... akkor magyarul beszélnek. Tehát ők így váltogatják. Attól függ, tehát a nyelvi repertoárba ahogy nekik könnyebben jön. Ök igy váltogatják. De ezt így szabad játék alatt annyira szépen meg lehet figyelni."

Ezek a vélemények a csoportszemlélet ideológiáiból következő eljárásoknak megfelelően dualitások sorával írják le a város szociális valóságát. Statikus és körülhatárolható identitásokat és nyelveket állítanak egymással a „vagy-vagy”, máskor az „is-is” logikája szerint valamilyen viszonyba, pillanatok helyett befejezettséget, sokféleség helyett dualizmusok sorát, hálózódás helyett elágazásokat, fluiditás helyet váltásokat, feszültségek helyett egyértelmüséget, dinamika helyett stabilitást láttatnak.

E kétféle szemlélet ugyanakkor nem egymástól függetlenül létezik. A csoportszemlélet perspektívájából kiindulók folyton szembesülnek azzal, hogy kategóriáik elégtelenek és alkalmatlanok a lokális nyelvi valóság leírására, mert azt olyan dinamizmusok és komplexitás uralja, amiröl így nem tudnak számot adni (erről tanúskodnak az óvónő olyan megjegyzései is, mint hogy ,,erre nagyon nehéz válaszolni”). És fordítva, a feszültség, a dinamika és a sokféleség fogalmaival jellemzett perspektíva diskurzusaira folyamatosan hat ez a másik, amelyik statikus és elhatárolható csoportok viszonyrendszerében láttatja a világot tudósokkal és laikusokkal egyaránt. Amikor beszélgetőtársainkkal ezeket a kérdéseket tárgyaltuk, arra sarkalltuk őket, hogy ők is a csoportszemlélet kategóriái (mint például a romani nyelv és a magyar nyelv) mentén adjanak számot nyelvi gyakorlataikról (e dilemmához vö. PACHNÉ HELTAI 2017a: 8-9, 190). Ezek a kategóriák persze számukra is ismerősek, hiszen - bár mindennapjaik beszédmódjai ezekkel pontosan nem írhatók le, nem feltétlen és csak eszerint szerveződnek - ők is részesei ugyanannak a helyi és tágabb valóságnak, mint mások. Nyelvi és etnikus kategóriák közötti választások várnak rájuk mindenhol. Annak, aki valamilyen viszonyba került azzal a társadalmi kategóriával, hogy roma, elkerülhetetlen, 
hogy e statikus rendszerben keresse a helyét. Mivel ezek a nemzetállami mátrixba illeszkedő fogalmak, a beszélöknek egyéni és közösségi szinten is arra van lehetőségük, hogy a ,vagy-vagy”, a „,nem-hanem” és a lényegileg alig különböző ,,isis" logikája mentén gondolkodjanak ezekről. Utóbbi csak látszólag más minőség, mint az előbbiek, hiszen ugyanúgy a dualitásra koncentráló redukciót igényel. Jelen társadalmi viszonyaink és diskurzív gyakorlataink nem nyújtanak lehetőséget arra, hogy az érintettek úgy járjanak el e kérdésekben, ahogy azt egyébként kutatásunk során beszélgetőtársainktól helyben tapasztaltuk. Ezek az elképzelések ma csak a margón lehetnek jelen.

4. Elmozdulás a margóról. A dolgozat előző fejezete bemutatta azt a szemléletmódot, ami a tárgyalt lokalitásban a csoportszemlélet alternatívájaként, kiegészítőjeként jelen van. Ez a fejezet azzal a kérdéssel foglalkozik, hogy hogyan jeleníthető meg ez a szemlélet tudományos diskurzusokban. E cél érdekében a szuperdiverzitás koncepcióját veti vizsgálat alá.

A szuperdiverzitás bizonyos tekintetben a csoportszemlélet alternatívájának tekinthető. Lényegi vonása, hogy nyelv, etnicitás, vallás és származási ország hagyományosnak tekintett csoportteremtő tengelyei mellett számos újabb, kevésbé statikusként, inkább változóként elgondolt tengely mentén írja le a globalizációban átalakuló társadalmak sokféleségét (VERTOVEC 2007, 2010). A koncepció, ahogy ezt kritikusai meg is jegyzik, kifejezetten az úgynevezett globális északhoz (ez a demokratikus társadalmi berendezkedésü, elsősorban iparra és szolgáltatásokra építő országok összefoglaló neve), azon belül is elsősorban Nyugat-Európához kapcsolódik (PAVLENKO 2018). A szociolingvisztikában BLOMMAERT és RAMPTON (2011) vezették fel a szuperdiverzitást, még jelentést keresve neki, de mindenképpen annak a kritikai fordulatnak a részeként, amely a beszélés leírását annak egyes nyelvekhez (kódokhoz) kötése helyett a nyelvi erőforrásokra és regiszterekre koncentrálva végzi (magyarul tárgyalja HELTAI B. 2013: 219; PACHNÉ Heltai 2017a: 16-20). BlacKledGE-CREESE (2018: xxii) szerint a globális északon, elsősorban Nyugat-Európában a társadalomtudósok az elmúlt években azt érzékelik, hogy számos globalizációs folyamat a korábbi relatív homogén nemzetállami etnikai és nyelvi viszonyok megváltozásához vezet. Ilyen, az emberek közötti kapcsolatokat megváltoztató folyamatokként említi a szerzőpáros a migráció különféle módozatait, a gazdaság és az üzleti élet multinacionális átalakulását, vagy általában véve a technológiai fejlődést. Hangsúlyozzák, hogy a szuperdiverzitás több mint a különbségtételhez felsorakoztatott újabb változók sokasága, a lényeg a különbözőség komplexitásának felismerése. A szuperdiverzitásra mint szemléletmódra tekintenek, és a különbségtétel ideológiai orientációját hangsúlyosabbnak tartják, mint a különbségek leírásának lehetőségét. A szuperdiverzitást elhatárolják a „szociális különbségtétel romantikus-liberális megközelítésétől" (BLACKLEDGE-CREESE 2018: xxiii; további idézeteiben is saját fordításom - H. J. I.), azaz a multikulturalizmustól, de azt is hangsúlyozzák, hogy a koncepciónak ,szembe kell szállnia a különbségtétel illiberális orientációival”, és rendelkeznie kell a „diszkriminációs erőkkel szembeni kritika" (BLACKLEDGE-CREESE 2018: xxiii) potenciáljával. A közösségi 
létezés olyan formáit látják előremutatónak, amelyekben „az emberek konstruktív módon alakítják ki az együttélés módjait" (NOWICKA-VERTOVEC 2014 alapján BLACKLEDGE-CREESE 2018: xxx). Ez a szociális minta, amelyet a konvivialitás terminussal írnak le (BLACKLEDGE-CREESE 2018: xxx), a különbségekről való gondolkodás olyan irányú megváltozását jelenti, amely ,immár nem érti félre és egyszerüsíti le a 'kultúra' fogalmát birtokolható és másoktól megőrizhető etnikai tulajdonra" (GILROY 2006 alapján BLACKLEDGE-CREESE 2018: xxx). Mindezzel összefüggésben kiemelik, hogy a szuperdiverzitás olyan cselekvésorientált elmélet, amely felvállalja a társadalmi egyenlőtlenségek csökkentését.

A szuperdiverzitás orientációját a társadalmi viszonyok leírásában jól alkalmazhatónak vélő szakemberek szerint a nyugat-európai társadalmi valóság megváltozott. Például nagy világvárosok után az elmúlt két évtizedben európai középvárosok (Malmö, Brüsszel, Frankfurt stb.) is úgynevezett többségi-kisebbségi városokká váltak vagy válnak (GELDOF 2018: 45), amelyekben ,a más, nem ugyanolyan" lakosok száma összeadva nagyobb, mint a hajdan a többséget alkotóké. A szuperdiverzitás orientációját követve ez a megnövekedett, új társadalmi sokféleség nem írható le pusztán a vallási, etnikai és nyelvi csoportok kategóriáival. Ez ugyanis a valóságnak a csoportszemlélet hagyományos ideológiái mentén történő leegyszerüsítése lenne. De e gondolatmenet szerint ugyanígy megkérdöjeleződik a multikulturalizmus szintén csoportszemléleten alapuló ideológiája is, azaz a csoportok sokféleségének és a csoportok egymás mellett éléséről szóló elképzeléseknek az ünneplése. Szintén problematikussá válik az integráció elképzelése, mert bizonyos lokalitásokban immár nem egyértelmü, hogy mi a többségi csoport és az általa diktált norma, illetve utóbbi hogyan érvényesíthető. GELDOF (2018: 53) szerint szuperdiverz kontextusokban az integráció helyett a részvétel lehet a kulcsmozzanat az egyének számára is, amihez az interkulturális kompetencia és a diverzitás-érzékenység kulcsfontosságú készségek. A szuperdiverzitás orientációja figyel a múltnak a kulturális örökség létrehozásának folyamatában ki nem választott, nem hagyományozott eseményeire, mozzanataira. Ezeknek a figyelmen kívül hagyott, nem jelölt, törölt meghatározottságoknak az újrafelfedezése segítheti a megnövekedett sokféleség kezelését, a különbségek mellett mindig meglévő azonosságokra való koncentrálást (DEUMERT 2018).

A nyelvi-etnikai komplexitás nem csak a nyugat-európai nagyvárosok és régiók jelenkori fejleményeként értelmezhető. BLACKLEDGE-CREESE felhívják a figyelmet arra, hogy a szuperdiverzitás történeti perspektívában való alkalmazása „sok lehetőséggel kecsegtet” (2018: xxv), GELDOF szerint pedig a szuperdiverzitás nem pusztán urbánus jelenség: sok kisebb városban, vidékies térségben is megnövekedett az elmúlt évtizedekben az etnikai diverzitás (2018: 45, magyar vonatkozásokhoz vö. PACHNÉ HELTAI 2016, 2017b). A szuperdiverzitás koncepciójának vannak olyan vonásai, amelyek egybevágnak annak az orientációnak a jellemzőivel, amelyek az e dolgozatban bemutatott lokalitásban a csoportszemlélet alternatívájaként megjelennek. Ilyen például a nyelvi és etnikai identitás sokszempontú alakulásának figyelembevétele vagy a különbözőség komplexitásának felismerése. A tárgyalt lokalitásban is komplex vallási, etnikai és nyelvi sokféleség tárható fel. A település társadalmi komplexitását a református paraszti rétegek, 
a római katolikus vallású főnemesi család, illetve az uradalmán élő cselédek, valamint a századokkal ezelött Kárpátaljáról betelepült szegényebb görögkatolikusok egyaránt formálják (LENGYEL 2004). Ehhez járulnak a 20. század második felében az iparosítással, majd a 90-es évektől annak kudarcával kapcsolatos változások, valamint az a tény, hogy a város ennek kapcsán két falu összevonásával keletkezett, és kifejezetten szervetlen (túl gyors és nem valós társadalmi igényeken alapuló) fejlődésen ment keresztül az elmúlt évtizedekben. A romaként számon tartott helyiek esetében a folyamatos (jellemzően környékbeli településekröl való) bevándorlás mellett a valláshoz és munkavállaláshoz kapcsolódó globalizációs jelenségek jellemzők. (A fentiekhez részletesen 1. HeLTAI 2019b). E körülmények következtében és a jelen tendenciák folytatódását feltételezve várható a város többségi-kisebbségi jellegüvé válása. Párhuzamosan ezzel például nehezen értelmezhető a városi oktatási rendszerben az integráció kulcsszava. A csoportszemlélet perspektívájából e változások úgy írhatók le, hogy egyre kevesebb nem roma és egyre több roma él a városban. A szuperdiverzitás szemléletének alkalmazásával lehetővé válik, hogy a tudományos megközelítések elszakadjanak ettől az értelmezéstől, és hatékonyabban keressék a konvivialitás támogatásának lehetőségeit - például a részvétel kulcsszava mentén. Ez jelentheti többek között azoknak a nem csak a magyar nyelvhez kapcsolódó nyelvi gyakorlatoknak az emancipációját is, amelyeket a kutatócsoport etnográfiai munkája során feltárt és leírt, illetve amelyeket az oktatásba a transzlingváló pedagógia alkalmazásával bevezet (JANI-DEMETRIOU 2017; HeLTAi et al. 2017; HelTAi 2019a). Ez a törekvés felkarolja és a tudományos leírás részévé teszi azt a szemléletmódot, amely az érintettek gondolkodását sok tekintetben meghatározza. Összekapcsolva a tudományosság fogalmait és a beszélők mindennapi nyelvi ideológiáit hozzájárul ahhoz, hogy az érintettek társadalmi nexusai és ezáltal esélyei szélesedjenek, életútjuk ne feltétlenül a marginalitáshoz kötődjön.

5. Záró megfontolások. A szuperdiverzitás cselekvésorientált megközelítés. Ez azt jelenti, hogy nem csak leírja a valóságot, hanem alakítani is szándékozik azt. Ez felvet dilemmákat. A szemléletet alkalmazó társadalomtudósok a szuperdiverzitást (a csoportszemlélethez képest) hatékony koncepciónak gondolják a békés társadalmi együttélés kialakításához, hatalom és alávetettség nyugati típusú elrendeződéseinek átalakításához. Segítségével feltárható a társadalmi viszonyok olyan komplexitása és dinamikája, amit a csoportszemlélet töröl a vizsgálódó szemei elől. Kérdéses azonban, hogy ezek normává tétele hozzájárul-e (és hogyan) a nagyobb társadalmi egyenlőség eléréséhez, tehát hogy nagyobb közjóhoz vezető létállapot-e a szuperdiverzitásban megvalósuló átmenetiség és a sokféleség, mint a (homogenitás felé tartó) csoportokba való rendeződés.

DELEUZE és GUATTARI Rizóma című esszéjükben megjegyzik, hogy ,a nyugati gondolkodás bosszantó jellegzetessége, hogy a kifejezéseket és a cselekvéseket külső vagy transzcendens végső célokra vezeti vissza, ahelyett, hogy azokat immanens módon a bennük rejlö érték alapján ítélné meg" (1996: o. n.). A csoportszemlélet és a szuperdiverzitás koncepcióiban egyaránt rejlik érték, de egyiket sem szükségszerü végcélként értelmezni. BAHTYIN szerint a nyelvi komplexitás a nyelvre párhuza- 
mosan ható centripetális (standardizációs) és centrifugális (destandardizációs) erők összjátékában alakul (BODÓ 2016b). Ezt a feszültséget sem a csoportszemlélet, sem a szuperdiverzitás szemlélete nem adja vissza. Előbbi csak a centripetális, utóbbi viszont csak a centrifugális erők hatásait vizsgálva írja le a társadalmi viszonyokat.

Fentiek alapján amellett érvelek, hogy a szuperdiverzitás koncepciójával leírható minták feltárása társadalmi viszonyainkban nem jelenti sem azt, hogy ne lennének a csoportalakítás irányába ható társadalmi erők, sem annak kényszerét, hogy végső céllá tegyük ezen erők semlegesítését, a komplexitás ünneplését, a társadalmi elrendeződések ilyen irányú átalakítását vagy átalakulásának segítését.

JASPERS (2019) arra int, hogy bár a politika és a közélet iránymutatást vár a tudománytól, a tudósok társadalmi kérdésekben mégsem viselkedhetnek az igazság letéteményeseiként. Érvelése szerint a társadalomtudomány rendszerint elég diverz ahhoz, hogy mindenki bizonyíthassa a maga igazát, ezért érdemesebb a lehetőségeket mérlegelni, mint egy-egy orientáció mellett ideológiailag elkötelezett érvelést folytatni. Ebben a dolgozatban a lehetőségek mérlegelésére tettem kísérletet. Az első fejezetben arra irányítottam a figyelmet, hogy a csoportszemlélet hagyományai mind a közélet, mind a tudományos diskurzusok tekintetében meghatározzák, hogyan tekintünk a romákkal kapcsolatos társadalmi kérdésekre. A második fejezetben bemutattam, hogy azok, akik e diskurzusok érintettjei, a vizsgált lokalitásban máshogy értelmezik az őket körülvevő valóságot. Végül megvizsgáltam, hogy az e kettősségből adódó feszültségek mennyiben kezelhetők a szuperdiverzitás koncepciójának alkalmazásával.

A csoportszemlélet hegemonikus jelenléte kizárja a megkérdezettekre jellemző szemlélet érvényesítését a közéleti és tudományos diskurzusokban. Ezen változtathat a szuperdiverzitás orientációjának alkalmazása. Ugyanakkor nincs ok azt gondolni, hogy a szuperdiverzitás átveheti a csoportszemlélet helyét mint a társadalmi létezés egyetlen elismert vagy üdvös módját leíró és előíró megközelítés. lexitás.

Kulcsszók: szuperdiverzitás, csoportszemlélet, romák, nyelvi és etnikai komp-

\section{Hivatkozott irodalom}

AGHA, AsIF 2007. The object called language and the subject of linguistics. Journal of English Linguistics 35: 217-235. https://doi.org/10.1177/0075424207304240

ARATó MÁTYÁs 2014. Cigányok, nyelvek, oktatás és tudomány. Új Pedagógiai Szemle 2014/9-10: 36-46.

BABUSIK FERENC 2004. Legitimacy, statistics and research methodology. Who is Romani in Hungary today and what are we (not) allowed to know about roma. Roma Rights Quarterly 2004/2: 14-18.

BALÓ ANDRÁS MÁRTON 2017. Oláh cigány dialektusok Magyarországon. In: CSERTI CSAPÓ TIBOR szerk., Romológia ,akkor és most”. PTE BTK NTI Romológia és Nevelésszociológia Tanszék, Pécs. 1-8. 
Blackledge, Adrian - CReEse, Angela 2018. Language and superdiversity. An interdisciplinary perspective. In: CREESE-BLACKLEDGE eds. 2018: xxi-xlv. https:// doi.org/10.4324/9781315696010

BLOMMAERT, JAN - BEN RAMPTON 2011. Language and superdiversity. Diversities 13/2: 1-22.

BODÓ CSANÁD 2014. Nyelvi ideológiák a magyar nyelvi változók kutatásában. Magyar Nyelv 110: 266-284.

Bodó CsAnÁd 2016a. Nyelvi ideológiák és különbségek. Institutul Pentru Studierea Problemelor Minorităților Naţionale, Cluj-Napoca.

BODÓ CSANÁD 2016b. „Vittem az ünüt az úlicába”: Heteroglosszia, diverzitás és standardizáció a moldvai magyar nyelvi revitalizációban. Általános Nyelvészeti Tanulmányok 28: $37-56$.

BRUBAKER, ROGERS 2002. Ethnicity without groups. European Journal of Sociology 43: 163-189. https://doi.org/10.1017/S0003975602001066

BRUBAKER, ROGERS 2004. Ethnicity without groups. Harvard University Press, Cambridge (MA).

BRUBAKER, RogERS - FEISCHMIDT, MARGIT - FoX, JON - GRANCEA, LiANA 2011. Nacionalista politika és hétköznapi etnicitás egy erdélyi városban. L'Harmattan, Budapest.

CREESE, ANGELA-BLACKLEDGE, AdRIAN eds. 2018. The Routledge Handbook of Language and Superdiversity. Routledge, Abingdon. https://doi.org/10.4324/9781315696010

Deleuze, Gilles - GuATtARI, FeliX 1996. Rizóma. Ex Symposion 1996/15-16: 1-17.

DEUMERT, ANA 2018. The multivocality of heritage. In: CREESE-BLACKLEDGE eds. 2018: 149-164. https://doi.org/10.4324/9781315696010

DomingueZ, Virginia R. 1989. People as subject, people as object. Selfhood and peoplehood in contemporary Israel. University of Wisconsin Press, Madison.

ENSZ 1992. Nyilatkozata nemzeti vagy etnikai, vallási és nyelvi kisebbségekhez tartozó személyek jogairól. A Közgyûlés 47/135. sz. Határozata. http://adattar.adatbank. transindex.ro/nemzetkozi/dec-h.htm (2019. 11. 23.)

ERDŐS KAMILL 1958. A magyarországi cigányság. Néprajzi Közlemények 3: 152-173.

GAL, SusAn 2008. Language and political space. In: Auer, PETER - SCHMIDT, JÜrgeN ERICH eds., Language and Space. Mouton de Gruyter, Berlin - New York. 33-50.

GELDOF, DIRK 2018. Superdiversity as a lens to understand complexities. In: CREESEBLACKLEDGE eds. 2018: 30-42. https://doi.org/10.4324/9781315696010

GILROY, PAUL 2006. Multiculture in times of war. An inaugural lecture given at the London School of Economics. Critical Quarterly 8/4: 27-45. https://doi.org/10.1111/ j.1467-8705.2006.00731.x

HELTAI BORBÁla ÉVA 2013. Nyelvcsere és migráció egy többnyelvü hazai beszélöközösségben. In: KONTRA MIKLÓs - NÉMETH MiKLÓs - SinKOVICS, BALÁzS szerk., Elmélet és empíria a szociolingvisztikában. Válogatás a 17. Élőnyelvi Konferencia elöadásaiból. Gondolat Kiadó, Budapest. 219-236.

HELTAI JÁNOS IMRE 2015. A romani és a beás nyelvi tervezés lehetőségei és kihívásai Magyarországon. Regio 23/4: 27-57. http://dx.doi.org/10.17355/rkkpt.v23i4.84

HELTAI JÁNOS IMRE 2019a. Translanguaging instead of Standardisation. Writing Romani at School. Applied Linguistics Review. Ahead of Print. https://doi.org/10.1515/ applirev-2018-0087 
Heltai JÁnOs ImRE 2019b. Szuperdiverzitás Szabolcsban. In: BöLCSKEI ANDREA szerk., Protestantizmus, identitás és hagyomány a nyelvben. Károli Gáspár Református Egyetem - L'Harmattan Kiadó, Budapest. 149-172.

HELTAI JÁNOS IMRE - JANI-DEMETRIOU BERNADETT - KEREKESNÉ LÉVAI ERIKA - OLEXA GERGELY 2017. Transzlingváló Osztálytermek Tiszavasváriban. Új Pedagógiai Szemle 67/11-12: 28-49.

HoRvÁTH KATA - KovAi CECÍLIA 2010. A cigány-magyar különbségtétel alakulása egy észak-magyarországi faluban. anBlokk 2010/4: 39-41.

IRVINE, JUdiTh T. - GAL, SUSAN 2000. Language ideology and linguistic differentiation. In: KROSKRITY, PAUL V. ed., Regimes of language. Ideologies, polities and identities. School of American Research Press, Santa Fe. 35-84.

JANI-DEMETRIOU BERNADETT 2017. Cigány gyerekek az iskolában: társas beszélés és társas megismerés. In: LADÁNYI MÁRIA - HRENEK ÉVA szerk., Témák és szempontok a nyelvhasználat vizsgálatában. Hallgatói tanulmányok. ELTE BTK Alkalmazott Nyelvészeti Tanszék, Budapest. 61-70.

JASPERS, JÜRGEN 2019. Authority and morality in advocating heteroglossia. Language, Culture and Society 1: 83-105. https://doi.org/10.1075/lcs.00005.jas

JørGENSEN, J. NormAnN 2008. Polylingual languaging around and among children and adolescents. International Journal of Multilingualism 5: 161-176. https://doi.org/ 10.1080/14790710802387562

KEMÉNy, IstVÁN - JANKY, BÉLA 2006. Roma Population of Hungary 1971-2003. In: KEMÉNY, IsTVÁN ed., Roma of Hungary. East European Monographs. Social Science Monographs. Atlantic Research and Publ., New York. 70-225.

KONTRA MIKLÓS 2003. Cigányaink, nyelveik és jogaik. Kritika 1: 24-26.

Kovai CECília 2017. A cigány-magyar különbségtétel és a rokonság. L’Harmattan, Budapest.

KSH 2013. 2011. évi népszámlálás 3. Országos adatok. Központi Statisztikai Hivatal, Budapest. http://www.ksh.hu/nepszamlalas/teruleti_adatok (2019. 11. 23.)

LADÁNYI, JÁNOS - SZELÉNYI, IVÁN 2001. The social construction of roma ethnicity in Bulgaria, Romania and Hungary during the market transition. Review of Sociology 7: 79-134. https://doi.org/10.1556/revsoc.7.2001.2.5

LAKATOS SZILVIA 2012. A romani nyelv közösségi használatának és közoktatási helyzetének vizsgálata Magyarországon. Doktori disszertáció. PTE BTK, Pécs.

LANDAUER ATTILA 2004. Utak és problémák a magyarországi cigánykutatásban. In: NAGY ATTILA - PÉTERFI RITA szerk., A feladatra készülni kell. A cigányság kulturális beilleszkedése és a közkönyvtár. OSZK - Gondolat Kiadó, Budapest. 13-46.

LENGYEL GABRIELLA 2004. Tiszavasvári Cigány népessége. In: KEMÉNY ISTVÁN - JANKY BÉLA - LENGYEL GABRIELlA szerk., A magyarországi cigányság 1971-2003. Gondolat - MTA Etnikai-nemzeti Kisebbségkutató Intézet, Budapest. 129-146.

LePpänen, SirPa - PeURONEn, SAIJA - WeStinen, Elina 2018. Superdiversity perspective and the sociolinguistics of social media. In: CREESE-BLACKLEDGE eds. 2018: 30-42. https://doi.org/10.4324/9781315696010-4

MAKONI, SINFREE - PENNYCOOK, ALASTAIR 2006. Disinventing and Reconstituting Languages. In: MAKOnI, SINFreE - PENNYCOOK, AlASTAIR eds., Disinventing and Reconstituting Languages. Multilingual Mattters, Clevedon. 1-41. 
Magyarország Alaptörvénye 2011.https://www.keh.hu/magyarorszag_alaptorvenye/1515Magyarorszag_Alaptorvenye\&pnr=1 (2019.06. 08.)

Magyar Országgyülés 2011. 2011/CLXXIX. Törvény a nemzetiségek jogairól. https://net. jogtar.hu/jogszabaly?docid=A1100179.TV\&timeshift=20190426 (2019. 06. 08.)

MARUSHIAKOVA, ELENA - POPOV, VESSELIN 2001. Historical and ethnographic background: Gypsies, Roma, Sinti. In : GuY, WILL ed., Between past and future. The Roma of Central and Eastern Europe. University of Hertfordshire Press, Hertfordshire. 33-53.

Matras, Yaron 2002. Romani. A linguistic introduction. Cambridge University Press, Cambridge.

MATRAS, YARON 2005. The classification of Romani dialects. A geographical-historical perspective. In: Schrammel, BARBARA - HALWACHS, DiETER W. - AMBrosch, GERD eds., General and applied Romani linguistics. Proceedings from the 6th International Conference on Romani Linguistics. Lincom Europa, München. 7-26.

MATRAS, YARON 2015. Transnational policy and 'authenticity' discourses on Romani language and identity. Language in Society 44: 295-316. https://doi.org/10.1017/ S0047404515000202

MiLROY, JAMES 2001. Language ideologies and the consequences of standardization. Journal of Sociolinguistics 5: 530-555. https://doi.org/10.1111/1467-9481.00163

NAGY PÁL 2007. „Gádzsósodás - cigányosodás”. Akkulturáció és parasztosodás a cigányok magyarországi történetében. Amaro drom 2007/2: 20-22.

Nowicka, Magdalena -Vertovec, Steven 2014. Comparing convivialities: dreams and realities of living-with-difference. European Journal of Cultural Studies 17: 341-356. https://doi.org/10.1177/1367549413510414

ORsós ANNA 2012. A beás nyelv megőrzésének lehetőségeiröl. PTE BTK Oktatáskutató Központ - Virágmandula Kft., Pécs.

PACHNÉ HelTAI BORBÁlA 2016. Változó nyelvi gyakorlatok és a mobilitás új formái egy többnyelvü településen. Nexusanalízis egy online társalgásról. In: BARTHA CSILLA szerk., A többnyelvüség dimenziói: terek, kontextusok, kutatási távlatok. Általános Nyelvészeti Tanulmányok 28. Akadémiai Kiadó, Budapest. 307-320.

PACHNÉ HeltAi BORBÁla 2017a. Nyelvcsere és szezonális migráció egy többnyelvü magyarországi közösségben. Nyelvi gyakorlatok, ideológiák és kommodifikáció társadalmi folyamatok nexusában. Doktori disszertáció. ELTE BTK, Budapest.

Pachné Heltai, Borbála 2017b. Multilingualism and Seasonal Migration. Linguistic Practices of Finnish House Owners in a German Minority Village in Southern Hungary. Folia Uralica Debreceniensia 24: 163-178.

PAVlenKo, ANeTA 2018. Superdiversity and why it isn't. In: SchMENK, BARBARA BREIDBACH, STEPHAN - KÜSTER, LUTZ eds., Sloganization in Language Education Discourse Conceptual Thinking in the Age of Academic Marketization. Multilingual Matters, Bristol. 142-168. https://doi.org/10.21832/9781788921879-009

PENNYCOOK, AlASTAIR 2018. Repertoires, registers, and linguistic diversity. In: CREESEBLACKLEDGE eds. 2018: 3-15. https://doi.org/10.4324/9781315696010

PÉNZES JÁNOS - TÁTRAi PATRIK - PÁSZTOR ISTVÁN ZoLTÁN 2018. A roma népesség területi megoszlásának változása Magyarországon az elmúlt évtizedekben. Területi Statisztika 58: 3-26. 
Skutnabb-Kangas, Tove - Miklós Kontra - Phillipson, Robert 2006. Getting Linguistic Human Rights Right. A Trio Respond to Wee (2005). Applied Linguistics 27: 318-324. https://doi.org/10.1093/applin/aml006

SzALAi ANDREA 2006: Egységesség? Változatosság? A cigány kisebbség és a nyelvi sokféleség. Nyelvtudományi Közlemények 103: 163-204.

SZALAI ANDREA 2007. Egységesség? Változatosság? A cigány kisebbség és a nyelvi sokféleség. In: BARTHA CsILlA szerk., Cigány nyelvek és közösségek a Kárpát-medencében. Nemzeti Tankönyvkiadó, Budapest. 20-51.

TÁlos ENDRE 2001. A cigány és a beás nyelv Magyarországon. In: KovALCSIK KATALIN szerk., Tanulmányok a cigányság társadalmi helyzete és kultúrája köréből. Tanítók kiskönyvtára 9. IFA-OM-ELTE, Budapest. 317-324.

VerTOVEC, STEVEN 2007. Super-diversity and its implications. Ethnic and Racial Studies 30: 1024-1054. https://doi.org/10.1080/01419870701599465

Vertovec, Steven 2010. Towards post-multiculturalism? Changing communities, contexts and conditions of diversity. International Social Science Journal 199: 83-95. https://doi.org/10.1111/j.1468-2451.2010.01749.x

WeE, LiONEL 2005. Intra-Language Discrimination and Linguistic Human Rights. The Case of Singlish. Applied Linguistics 26: 48-69. https://doi.org/10.1093/applin/amh038

WEI, LI 2011. Moment analysis and translanguaging space. Discoursive construction of identities by multilingual Chinese youth in Britain. Journal of Pragmatics 43: 1222-1235. https://doi.org/10.1016/j.pragma.2010.07.035

WeSSENDORF, SusAnNE 2018. „All the people speak bad English”. Communicating across differences in a super-diverse context. In: CREESE-BLACKLEDGE eds. 2018: 57-70. https://doi.org/10.4324/9781315696010

\section{Dynamics and complexity in the linguistic and ethnic self-identification of the Roma}

The criteria of belonging to the group (or groups) of the Roma are traditionally manifold: language, ethnicity, sociocultural characteristics, historical particularities, etc. Nevertheless, the categorizations are constantly divided into dualities: Gypsy and not Gypsy, Boyash and not Boyash, Hungarian Roma and Vlah Roma, Romani and not Romani, or even monolingual and bilingual. This logic, which invokes the imagery of stable groups, was called groupism by ROGERS BRUBAKER $(2002,2004)$. Drawing on fieldwork experiences, my paper introduces the idea that the categories of groupism are only restrictedly valid in the locus of our research, and the Romani participating in this research speak about language and ethnicity partially differently. I examine to what extent the concept of superdiversity (BLACKLEDGE-CREESE eds. 2018) is capable to adapt this alternative approach into scientific inquiry, and how it could contribute to the investigation and the management of linguistic and social issues associated with the Roma.

Keywords: Roma, groupism, translanguaging, superdiversity.

HELTAI JÁNOS IMRE Károli Gáspár Református Egyetem 